Using Political Psychology to Understand Populism, Intellectual Virtues, and Democratic Backsliding

\author{
Ingrid J. Haas, Ph.D. \\ Department of Political Science \\ Center for Brain, Biology, and Behavior \\ University of Nebraska-Lincoln \\ Email: ihaas2@unl.edu
}

Invited chapter to appear in G. R. Peterson, M. C. Berhow, \& G. Tsakiridis (Eds.), Engaging Populism: Democracy and the Intellectual Virtues. Palgrave.

Word Count: 6108

Manuscript draft 2020-08-31. Please do not cite without permission. 


\begin{abstract}
Political scientists have argued that populism is an ideology that can occur on both the left and right, whereby people begin to see politics as a battle between the people and a powerful elite that fails to represent the people's interest and are attracted to political candidates who vow to fight corruption. In this chapter, I examine how research in political psychology may help to explain the motivations underlying citizens' attraction to populist ideologies and political candidates. I argue that the same cognitive processes driving people toward populism are those that undermine the intellectual virtues, which in turn, decreases support for democratic norms and can lead to democratic backsliding. In particular, I examine the role of affective states like threat, uncertainty, and anger in driving both increased support for populism and decreased support for open-minded discussion and debate. I also consider whether and how misinformation and attraction to conspiracy theories mediate the link between populism and antidemocratic tendencies.
\end{abstract}

Keywords: populism, political psychology, political behavior, political cognition, emotion, conspiracy, intellectual virtues, democratic backsliding 


\section{Using Political Psychology to Understand Populism, Intellectual Virtues, and Democratic Backsliding}

Recent commentaries have suggested that populism is on the rise worldwide and this has resulted in a new or renewed interest in understanding both the roots and the consequences of populism for democracy. In order to determine whether this increased public focus on populism in recent years is illusory or supported by empirical evidence, scholars have attempted to document changes in populist discourse around the world through the creation of resources such as the Global Populism Database (Hawkins et al., 2019; Lewis et al., 2019a; Lewis, Clarke, \& Barr, 2019b). The creation of this database was an attempt to quantify the use of populist rhetoric in over 40 countries using text analysis, demonstrating that there has indeed been a sizeable increase in the number of populist leaders since the year 2000 , including notable gains in power in Europe and North America (Hawkins et al., 2019; Lewis et al., 2019a). In the United States, the 2016 Presidential election included populist appeals from candidates on both the political right (Donald Trump) and left (Bernie Sanders), resulting in the election of a president (Donald Trump) who clearly utilizes populist appeals regardless of whether or not he actually subscribes to a populist ideology (Hawkins \& Littvay, 2019). This rise in populism, by itself, is not necessarily problematic as there is nothing normatively "wrong" with populism--or the desire of average people to reclaim some power from political elites. Indeed, in the face of corruption or elitism in a democratic system, populist ideology is likely to be an attractive recourse. However, concern about increased populist discourse has emerged because of the observed decline in support for democratic norms that has been documented over roughly the same time period. 
Organizations that track and evaluate democratic backsliding around the world have shown notable decreases in democratization in the last two decades. For example, The Economist Intelligence Unit's (EIU) Annual Democracy Index shows a decline in the average global democracy score from 2006 to 2019 ("Global democracy in retreat," 2020) and Freedom House notes that the number of countries showing a decline in democracy scores outnumbers those showing an increase over that same time period ("Freedom in the World 2019," 2019). By the EIU Democracy Index metric, the United States was downgraded from a "full democracy" to a "flawed democracy" in 2016 and in 2019 had a score of 7.96 out of 10, keeping it in the "flawed democracy" category ("Democracy Index 2019: A year of democratic setbacks and popular protest," 2019; "Global democracy in retreat," 2020). Freedom House rates the United States as "free," but notes declines in rule of law and increased discrimination against refugees and immigrants since (the election of Donald Trump in) 2016 ("Freedom in the World 2019," 2019). Public sentiment in the U.S. appears to be in line with these objective ratings, as recent public opinion data in the U.S. shows that only $39 \%$ of the population is satisfied with how democracy is working, and decreased satisfaction with democracy seems to be associated, at least in part, with a belief that elected officials do not care about "people like them" (Wike \& Schumacher, 2020). Along with declining trust in government and increased economic inequality, conditions are ripe for Americans to turn to alternative approaches to governing, like those offered by populist leaders.

This chapter will focus on understanding the political psychology of populism, by first examining how political scientists have studied populism in general, and in the U.S. context in particular, discussing the psychology of intellectual virtues, and offering a 
theoretical argument about how and why increased support for populism may lead to a decline in intellectual virtues, and, as a consequence, increased democratic backsliding. I focus mainly on what political science and psychology can contribute here, as other chapters in this volume will outline the philosophy of intellectual virtues (see Part II of this volume), as well as the history of populism in the U.S. (see Bloodworth, chapter 2), in greater detail.

\section{The Politics of Populism}

Political scientists have defined populism in a variety of ways, but at the core are ideas about how people view political elites (with distrust) and an us versus them mentality where "the people" are righteous and need to restore the balance of power in a political system (Mansbridge \& Macedo, 2019). This focus on the people is similar to the notion of popular sovereignty in a democratic system, but populists tends to adopt a more cynical approach to democracy than traditional theorists of participatory democracy (Dryzek \& Berejikian, 1993). Importantly, while populism is often discussed in relation to specific political movements, it can theoretically occur on both the political left and right, and arguably, should be conceptualized as an ideology rather than a specific set of policy opinions. Hawkins argues that populism should be thought of as a rhetorical style or discursive frame, with a focus on two key elements: people-centrism and anti-elitism (Hawkins \& Littvay, 2019; Hawkins \& Rovira Kaltwasser, 2019). Peoplecentrism is the idea that politics should reflect the desires of the common people, whereas anti-elitism is the view that elites are corrupt and no longer represent the will of the people. They argue that populist attitudes are actually latent and widely shared, such that many people hold these views and they can be activated in the right context. 
It is also important to separate the definition of populist ideology from related concepts, such as perceived corruption, belief in conspiracy theories, and antiimmigrant sentiment. Extant research has shown that populism is associated with perceived corruption and while much of this work has been correlational, there is some suggestion that corruption may precede the election of populist leaders (Hawkins \& Littvay, 2019). However, there seems to be a lack of experimental evidence here. A related, but separate, issue is whether populism is associated with belief in conspiracy theories. Conspiracy theories typically involve distrust of elites (whether political or otherwise), a belief that elites are responsible for negative outcomes, and a perception that the true cause of that negative outcome is being (intentionally) concealed (Douglas et al., 2019; Hofstadter, 1964). It is easy to see how a belief in conspiracy theories (especially political conspiracies) could be associated with populism, and indeed, that is what initial studies appear to show (Bergmann, 2018; Bergmann \& Butter, 2020). Survey data has shown a correlational relationship between populist attitudes and endorsement of conspiracies_especially those focused on global conspiracies and control of information (Castanho Silva, Vegetti, \& Littvay, 2017). Macro-level analyses have demonstrated a link between the degree of populist voting in a country and the number of people opposed to vaccination (Kennedy, 2019), an issue that is arguably tied to conspiracy theories about the medical field and scientific research. Indeed, some have argued that populist leaders may even strategically adopt and promote conspiracy theories as a way to increase support for their goals (Jessen, 2019; Prasad, 2020). Given the existing empirical work is correlational, we do not really know whether belief in populism is somehow causing endorsement of conspiracies or vice versa. Whereas 
the association with perceived corruption and conspiracy theories are, at least theoretically, separable from whether populism is occurring on the political left or right, anti-immigration sentiment is more likely to be associated with right-leaning populism. In an analysis comparing Latin American populism with European populism, Mudde and Rovira Kaltwasser (2013) argue that Latin American (left-leaning) populism is more likely to be inclusionary in terms of how "the people" are defined, whereas European (right-leaning) populism is more likely to be exclusionary in its definition of the people. The populism of the Trump presidency in the U.S. is clearly exclusionary in nature, as status threat and anti-immigration sentiment have been some of the core drivers of his support (Hooghe \& Dassonneville, 2018; Major, Blodorn, \& Blascovich, 2018; Mutz, 2018). While it seems likely that perceived corruption often precedes the growth of populist movements, endorsement of conspiracies and anti-immigrant sentiment may be correlates that are present only under specific conditions.

Given the lack of empirical work, it is still somewhat unclear whether perceived corruption, conspiracy endorsement, and anti-immigrant sentiment lead to the adoption of populist attitudes or vice versa. While research has convincingly argued these concepts are associated, there is a lack of empirical and especially experimental work outlining causal pathways. That said, the notion that populist attitudes are latent and can be activated by situational context may be helpful here, in that populist attitudes may, in part, be activated by things like perceived corruption and low trust in government, while also requiring that parties or leaders are using populist rhetoric and providing an outlet for these viewpoints (Hawkins \& Littvay, 2019). However, the extant literature suffers from a lack of clarity on many of these issues given conflicting 
definitions of populism and a lack of clarity and empirical evidence on proposed causal relationships among these variables.

Much of the recent discussion about populism in the academic literature has arisen both because of the observed increase in populist rhetoric in recent years, and because of the concern that populist movements may have a negative impact on democracy. The extant research examining the consequences of populism has focused on examining how populism influences political participation and support for democratic norms. There is mixed evidence with respect to these outcomes, and in many cases the evidence is again correlational, so whether these are truly consequences of populism remains a bit murky. That said, in general, the argument has been that populism may increase political participation by giving previously disillusioned voters a new way to express their views, and decrease support for democratic norms-more specifically, by undermining support for democratic elections and protections for civil rights and liberties, decreasing judicial oversight, and increasing media censorship (Hawkins \& Littvay, 2019). Indeed, while populism is consistent with some democratic values like popular sovereignty it may, by definition, be antithetical to some of other core tenants such as pluralism, tolerance, and compromise (Galston, 2018), especially once populists are in power (Mansbridge \& Macedo, 2019). So, what does the data show? First, with respect to political participation, a comparative experiment in Europe showed that populist messages can increase political engagement (Hameleers et al., 2018), but studies focused on Latin America have found that populism has no effect on participation (Houle \& Kenny, 2016) or may increase participation only for narrow segments of the population (Hawkins, 2010). Other work conducted in the Netherlands 
argues that the effect of populism on voting may be overstated, as populism also increases political discontent (Rooduijn, van der Brug, \& de Lange, 2016) and political cynicism (Rooduijn, Van der Brug, De Lange, \& Parlevliet, 2017). With respect to populism and democratic norms, Houle and Kenny (2016) found that populism tended to erode constraints on executive power in Latin America. Interestingly, in recent years, it seems to be the case that if populist movements result in declining democratic norms it does not happen right away, but more gradually over time, more commonly in second or third terms in office (Hawkins \& Littvay, 2019; Levitsky \& Ziblatt, 2018). So, while there is some evidence that populism is associated with democratic backsliding, the evidence is in some cases mixed and it seems clear that more empirical work is needed here.

In the United States, populism has garnered (re)new(ed) attention in recent years given the populist rhetoric of political candidates on both the left and the right, including Donald Trump and Bernie Sanders. Qualitative analyses of political speeches during the 2016 U.S. Presidential election suggest that both Trump and Sanders used populist rhetoric, and that populist attitudes were associated with increased support for both candidates in 2016, although for Sanders this was moderated by party identification such that populist attitudes only increased support among Democrats, whereas for Trump populist attitudes increased support regardless of party identification (i.e., among both Republicans and Democrats; Hawkins \& Littvay, 2019). Interestingly, these analyses also suggest that Trump's use of populism varies, suggesting it might be dependent at least to some extent on his speechwriters (Hawkins \& Littvay, 2019). More specifically, while Trump appears to often invoke ideas related to anti-elitism, he more 
rarely discusses "the people" (Bergmann \& Butter, 2020; Hawkins \& Littvay, 2019). This is not surprising, perhaps, given the perception that Trump appears to be high in trait narcissism (Nai \& Maier, 2018), although research on leader narcissism suggests that people may be willing to overlook narcissism in some cases-when the leader also displays positive traits like charisma, or people believe the leader to be effective in representing their values and obtaining their goals regardless of negative character traits (Williams, Pillai, Deptula, Lowe, \& McCombs, 2018). In sum, this work suggests that populist attitudes and ideology have been active in American politics in recent years, but there may be distinct strains of populism that are activated depending on the rhetoric of political candidates and leaders, as well as the openness of the people to these ideas as a function of current sociopolitical context.

\section{Emotion and the Intellectual Virtues}

While much work has been done to describe populist movements, there is a lack of research explaining the causes of support for populism, and more specifically, explaining the linkages between populism, the decline in intellectual virtues, and waning support for democratic norms. In this section, I suggest that research on the political psychology of emotion may help to clarify the causal mechanisms linking these phenomena together.

While there is disagreement in philosophy about the extent to which the intellectual virtues are intrinsic versus learned, philosophers have proposed a list of characteristics that are generally included in the list of intellectual virtues-openmindedness, tolerance, intellectual courage, intellectual autonomy, intellectual humility, and (the pursuit of) truth (see e.g., Battaly, 2008; Montmarquet, 1993; Zagzebski, 1996). 
Where political scientists and psychologists are sometimes hesitant to draw normative conclusions lest someone accuse them of bias, philosophers have no such qualms and have devoted many pages to determining what makes a psychological trait or characteristic a virtue versus a vice. Indeed, philosophers are very skilled at defining a characteristic first in a neutral way and then clarifying when that characteristic represents a virtue versus a vice as a function of context, an approach known as normative contextualism (Kidd, 2020). While people may vary in the degree to which they exemplify these traits, philosophers have argued that virtues like open-mindedness can be learned and developed over time (Battaly, 2008). This allows for the idea that the same person may behave differently over time, or in different situations, as well as the idea that similar behavior may be virtuous or not depending on the context the individual is in. For example, some of this work has focused on the notion that marginalized individuals may need to adopt "vices" (e.g., arrogance, closedmindedness) under some circumstances in order to fight oppression, and in that case, it may be unfair to characterize the trait as a vice (Dillon, 2012; Kidd, 2020). This has clear implications both for the idea that virtues (and vices) are expressed in contextdependent ways, and arguably, for the study of populism given individuals who adopt populist attitudes often view themselves as being marginalized.

While psychologists have not focused their efforts on intellectual virtues in the same way, there is a body of research on related traits in psychology, including openversus closed-mindedness, tolerance, prejudice, and some newer work on intellectual humility (e.g., Brandt, Chambers, Crawford, Wetherell, \& Reyna, 2015; Brandt, Reyna, Chambers, Crawford, \& Wetherell, 2014; Krumrei-Mancuso \& Rouse, 2016; Leary et al., 
2017; Mummendey \& Wenzel, 1999; Webster \& Kruglanski, 1994). Much of this work has focused on these traits as being aspects of individual personality, while still allowing for the idea that they might be somewhat context dependent. Indeed, a related literature has demonstrated that affect and emotion have important situational influences on the expression of these traits, and social and political cognition more generally (e.g., Marcus, Sullivan, Theiss-Morse, \& Stevens, 2005; Ray \& Zald, 2012; Storbeck \& Clore, 2007). Below, I provide a brief overview of current social psychological and neuroscientific understanding of emotion, and then discuss the impact of emotion on political cognition in more detail.

Psychologists have been studying the nature of affect and emotion for quite some time, and more recently this work has been incorporated into the study of political behavior via the study of political psychology. While psychologists continue to disagree about the exact nature of emotion and how specific affective experiences are represented in the brain (e.g., Lindquist, Satpute, Wager, Weber, \& Barrett, 2015; Lindquist, Wager, Kober, Bliss-Moreau, \& Barrett, 2012), there is general agreement on the idea that emotions can be either positively or negatively valenced (or some combination of the two; Cacioppo \& Berntson, 1994) and that even similarly valenced emotions can produce distinct behavioral outcomes depending on associated appraisals and motivation (Lerner \& Keltner, 2000; Marcus, Neuman, \& MacKuen, 2000). For example, while fear and anger are both negative emotions, fear may be more likely to produce avoidance behavior whereas anger is more likely to produce approach behavior (Lerner \& Keltner, 2001). So, in terms of politics, fear (or anxiety) might make people more likely to avoid a threatening situation and anger might make people more 
likely to engage in protest. With respect to attitudes about terrorism, for example, past research has shown that fear was associated with increased preference for defensive policies and deportation of immigrants, whereas anger was associated with expansion of the War on Terror following the terrorist attacks in the United States on September 11, 2001 (Skitka, Bauman, Aramovich, \& Morgan, 2006). A panel survey that focused on adoption of populist attitudes, specifically, found that anger was associated with increased support for populism, but fear was not (Rico, Guinjoan, \& Anduiza, 2017). While there is a clear link between emotion and political behavior, there is still more work to be done to understand how specific emotions differentially influence outcomes of interest.

Other work in social and political psychology has shown that emotion has varied impacts on cognitive processing, with implications for what philosophers have labeled the intellectual virtues. In particular, some negative emotions like fear and anxiety may have a negative impact on individual ability to engage in cognitive elaboration and openminded thinking. Fear, anxiety, and the associated threat response, in particular, are likely to cause a narrowing of attention that enables people to deal effectively with threats (Bar-Haim, Lamy, Pergamin, Bakermans-Kranenburg, \& van, 2007; Bishop, Duncan, Brett, \& Lawrence, 2004), but as a consequence tends to interfere with executive function-for example, decreasing working memory capacity (Lavric, Rippon, \& Gray, 2003). In the political domain, decreased executive function may be associated with decreased open-mindedness, leading people to double-down on existing beliefs and become more dogmatic. For example, in some of our own work, we found that when people are exposed to uncertain threats, in particular, they tended to respond with 
lower levels of political tolerance (Haas \& Cunningham, 2014). I have also found that uncertain threats decrease support for political compromise (Haas, 2016). This work is consistent with a wider literature in social psychology showing that threat (and sometimes uncertainty) can lead to defense of pre-existing views and closedmindedness (e.g., Greenberg, Pyszczynski, \& Solomon, 1986; McGregor, Zanna, Holmes, \& Spencer, 2001; Thorisdottir \& Jost, 2011). Thus, it would seem that many negative emotional experiences also have negative implications for the degree to which people behave in line with intellectual virtues like open-mindedness.

As discussed above, populist attitudes may be latent and activated by appropriate context. Populism seems to be especially relevant in historical contexts where the government is corrupt or perceived to be corrupt and political trust is low. This increases support for the idea that the people and elites are in conflict, and that the people need to take back control. The lack of political trust that characterizes populism is likely to be associated with an increased perception of political threat, or the idea that one's group is at risk given the current system of political power. Indeed, past research has argued that ingroup threat may be central to support for populist movements (Hameleers et al., 2018). This means that along with support for populism, distrust and threat are likely to also produce an increase in closed-minded cognition (the "black and white thinking" that characterizes populism) and perhaps also endorsement of conspiracy theories. There is, indeed, some correlational evidence that populism and conspiracy endorsement sometimes go hand-in-hand (Castanho Silva et al., 2017), and in some of our ongoing work, we find that political threat increases endorsement of conspiracy theories, especially for those individuals who are highly identified with a 
political group (Schneider \& Haas, manuscript in preparation). So, while the causal order is unclear given existing empirical data, it seems to be the case that political trust, threat perceptions, conspiracy endorsement, and adoption of populist attitudes are all related.

Finally, it is interesting to consider whether and how populist leaders might harness emotion to achieve their goals. It is possible that a populist movement starts with feelings of threat, fear, or anxiety, but shifts to anger once a target is clearly identified. The rhetoric of the leader may be one way in which this frustration is harnessed to propel people into action (e.g., voting for a populist political candidate; Hawkins \& Littvay, 2019). Populism may increase support for unconventional means like protest, or populist attitudes can be channeled into more traditional political behavior like voting but this is more likely when a charismatic leader is present (Hawkins \& Littvay, 2019). It is also possible that a charismatic leader might harness positive emotion by making people feel hopeful about the future. Research on emotion and politics suggests that both negative (e.g., anger) and positive (e.g., enthusiasm) emotions can be powerful motivating factors for political behavior (Marcus et al., 2000). This is likely not accidental, given political strategists are aware of the motivational push emotional investment from voters can bring to a campaign. Indeed, the success of the Trump campaign in 2016 has been attributed to many factors, but among them are the way in which the campaign channeled feelings of status threat for White Americans (Mutz, 2018), anger directed toward political elites (i.e., coastal liberals) and outgroups (e.g., racial/ethnic minorities, non-white immigrants; Hooghe \& Dassonneville, 2018; 
Major, Blodorn, \& Major Blascovich, 2016), while also promoting hope for change (e.g., borrowing Ronald Reagan's “Make America Great Again” slogan).

\section{Conclusion}

Democracy is predicated on the notion of popular sovereignty, which, at least in theory, requires that citizens participate in democratic governance and see value in upholding democratic norms. The democratic process can start to crumble when the people no longer believe that democracy is producing equitable outcomes, and perhaps especially when the people lose trust in institutions and political elites. The populist movements we have witnessed in recent years should have an easier time finding support when people experience low levels of political trust and high levels of political threat. Lack of trust and feelings of threat likely produce a range of negative emotional responses, including fear, anxiety, and anger, which in turn may lead to an increase in closed-minded thinking and intolerance. This emotional response also makes it more likely that people will be attracted to populist ideology and in some cases, conspiracy theories, given that both are focused on the idea of a corrupt elite with nefarious motives. This collection of psychological processes is also likely to undermine the democratic process, because once you decide that your political opposition is the enemy, it is no longer possible to value tolerance and institutional forbearance in the way necessary for a healthy democracy to function (Levitsky \& Ziblatt, 2018). Rather, the goal in this case is to reclaim power from the corrupt elite, in some cases by any means necessary. Research on emotion and political cognition suggests that this shift can happen relatively easily, and that it may actually be more difficult to promote the high-minded values (or intellectual virtues) that democracy requires, like open-minded 
deliberation, compromise, and tolerance given these values are easily undermined by a lack of trust and feelings of threat. Democratic backsliding is probably not the goal of populist movements, but rather, a byproduct of the emotional correlates and narrowed worldview that co-occur with the adoption of populist ideology. Populists may come to believe that if democracy is not working for them or their ingroup, there is no reason to uphold it as an ideal form of government.

So, is populism good or bad for democracy? It depends. If a democratic system has already been corrupted or failed, populism may be seen as a virtuous attempt to restore power to the people. But there is danger that populists will sacrifice democratic norms like minority rights, press freedom, or the value of elections in the attempt to gain power, or after that power has been obtained, especially in cases where the charismatic populist leader has authoritarian tendencies. In other words, populism in opposition may be good for democracy, but populism in power may be more likely to produce democratic backsliding (Mansbridge \& Macedo, 2019). As I have argued here, the link between populism and democratic backsliding is likely to be exacerbated by fundamental aspects of human psychology, where the emotions that lead to the adoption of populist ideology also undermine the intellectual virtues and support for democratic norms. 


\section{References}

Bar-Haim, Y., Lamy, D., Pergamin, L., Bakermans-Kranenburg, M. J., \& van, I. M. H. (2007). Threat-related attentional bias in anxious and nonanxious individuals: a meta-analytic study. Psychological Bulletin, 133(1), 1-24. doi: 10.1037/00332909.133.1.1

Battaly, H. (2008). Virtue epistemology. Philosophy Compass, 3/4, 639-663.

Bergmann, E. (2018). Conspiracy and populism: The politics of misinformation: Springer.

Bergmann, E., \& Butter, M. (2020). Conspiracy theory and populism. In M. Butter \& P. Knight (Eds.), Routledge Handbook of Conspiracy Theories. London: Routledge.

Bishop, S., Duncan, J., Brett, M., \& Lawrence, A. D. (2004). Prefrontal cortical function and anxiety: Controlling attention to threat-related stimuli. Nature Neuroscience, 7, 184-188.

Brandt, M. J., Chambers, J. R., Crawford, J. T., Wetherell, G., \& Reyna, C. (2015). Bounded openness: The effect of openness to experience on intolerance is moderated by target group conventionality. J Pers Soc Psychol, 109(3), 549-568. doi: $10.1037 / p s p p 0000055$

Brandt, M. J., Reyna, C., Chambers, J. R., Crawford, J. T., \& Wetherell, G. (2014). The Ideological-Conflict Hypothesis: Intolerance Among Both Liberals and Conservatives. Current Directions in Psychological Science, 23(1), 27-34. doi: $10.1177 / 0963721413510932$ 
Cacioppo, J. T., \& Berntson, G. G. (1994). Relationship between attitudes and evaluative space: A critical review, with emphasis on the separability of positive and negative substrates. Psychological Bulletin, 115, 401-423.

Castanho Silva, B., Vegetti, F., \& Littvay, L. (2017). The Elite Is Up to Something: Exploring the Relation Between Populism and Belief in Conspiracy Theories. Swiss Political Science Review, 23(4), 423-443. doi: 10.1111/spsr.12270

Democracy Index 2019: A year of democratic setbacks and popular protest. (2019). The Economist Intelligence Unit.

Dillon, R. S. (2012). Critical character theory: Toward a feminist perspective on "vice" (and "virtue"). In S. Crasnow \& A. Superson (Eds.), Out from the shadows: Oxford University Press.

Douglas, K. M., Uscinski, J. E., Sutton, R. M., Cichocka, A., Nefes, T., Ang, C. S., \& Deravi, F. (2019). Understanding Conspiracy Theories. Advances in Political Psychology, 40(S1), 3-35. doi: 10.1111/pops.12568

Dryzek, J. S., \& Berejikian, J. (1993). Reconstructive democratic theory. American Political Science Review, 87(1), 48-60.

Freedom in the World 2019. (2019). Freedom House.

Galston, W. A. (2018). The Populist Challenge to Liberal Democracy. Journal of Democracy, 29(2), 5-19. doi: 10.1353/jod.2018.0020

Global democracy in retreat. (2020, January 21). The Economist Intelligence Unit.

Greenberg, J., Pyszczynski, T., \& Solomon, S. (1986). The causes and consequences of the need for self-esteem: A terror management theory. In R. F. Baumeister (Ed.), Public self and private self. New York: Springer-Verlag. 
Haas, I. J. (2016). The impact of uncertainty, threat, and political identity on support for political compromise. Basic and Applied Social Psychology, 38(3), 137-152.

Haas, I. J., \& Cunningham, W. A. (2014). The uncertainty paradox: Perceived threat moderates the effect of uncertainty on political tolerance. Political Psychology, 35(2), 291-302.

Hameleers, M., Bos, L., Fawzi, N., Reinemann, C., Andreadis, I., Corbu, N., . . . Aalberg, T. (2018). Start spreading the news: A comparative experiment on the effects of populist communication on political engagement in sixteen European countries. The International Journal of Press/Politics, 23(4), 517-538.

Hawkins, K. A. (2010). Who mobilizes? Participatory democracy in Chavez's Bolivarian Revolution. Latin American Politics and Society, 52(3), 31-66.

Hawkins, K. A., Agilar, R., Castanho Silva, B., Jenne, E. K., Kocijan, B., \& Rovira Kaltwasser, C. (2019). Measuring populist discourse: The global populism database. Paper presented at the EPSA Annual Conference, Belfast, UK.

Hawkins, K. A., \& Littvay, L. (2019). Contemporary US populism in comparative perspective. Cambridge, UK: Cambridge University Press.

Hawkins, K. A., \& Rovira Kaltwasser, C. (2019). The ideational approach. In K. A. Hawkins, R. Carlin, L. Littvay \& C. Rovira Kaltwasser (Eds.), The ideational approach to populism: Concept, theory, and analysis. London: Routledge. Hofstadter, R. (1964). The paranoid style in American politics. Hooghe, M., \& Dassonneville, R. (2018). Explaining the Trump Vote: The Effect of Racist Resentment and Anti-Immigrant Sentiments. PS: Political Science \& Politics, 51(03), 528-534. doi: 10.1017/s1049096518000367 
Houle, C., \& Kenny, P. D. (2016). The Political and Economic Consequences of Populist Rule in Latin America. Government and Opposition, 53(2), 256-287. doi:

10.1017/gov.2016.25

Jessen, N. (2019). Populism and Conspiracy: A Historical Synthesis of American Countersubversive Narratives. American Journal of Economics and Sociology, 78(3), 675-715. doi: 10.1111/ajes.12275

Kennedy, J. (2019). Populist politics and vaccine hesitancy in Western Europe: An analysis of national-level data. European Journal of Public Health, 29(3), 512-516.

Kidd, I. J. (2020). Epistemic corruption and social oppression. In I. J. Kidd, Q. Cassam \& H. Battaly (Eds.), Vice epistemology: Theory and practice. New York: Routledge.

Krumrei-Mancuso, E. J., \& Rouse, S. V. (2016). The Development and Validation of the Comprehensive Intellectual Humility Scale. J Pers Assess, 98(2), 209-221. doi: $10.1080 / 00223891.2015 .1068174$

Lavric, A., Rippon, G., \& Gray, J. R. (2003). Threat-evoked anxiety disrupts spatial working memory performance: An attentional account. Cognitive Therapy and Research, 27, 489-504.

Leary, M. R., Diebels, K. J., Davisson, E. K., Jongman-Sereno, K. P., Isherwood, J. C., Raimi, K. T., . . Hoyle, R. H. (2017). Cognitive and interpersonal features of intellectual humility. Personality and Social Psychology Bulletin, 43(793-813).

Lerner, J. S., \& Keltner, D. (2000). Beyond valence: Toward a model of emotion-specific influences on judgment and choice. Cognition and Emotion, 14(4), 473-493.

Lerner, J. S., \& Keltner, D. (2001). Fear, anger, and risk. Journal of Personality and Social Psychology, 81(1), 146-159. doi: 10.1037//o022-3514.81.1.146 
Levitsky, S., \& Ziblatt, D. (2018). How democracies die: Broadway Books.

Lewis, P., Barr, C., Clarke, S., Voce, A., Levett, C., \& Gutierrez, P. (2019a, March 6). Revealed: the rise and rise of populist rhetoric, The Guardian.

Lewis, P., Clarke, S., \& Barr, C. (2019b, March 6). How we combed leaders' speeches to guage populist rise, The Guardian.

Lindquist, K. A., Satpute, A. B., Wager, T. D., Weber, J., \& Barrett, L. F. (2015). The Brain Basis of Positive and Negative Affect: Evidence from a Meta-Analysis of the Human Neuroimaging Literature. Cereb Cortex. doi: 10.1093/cercor/bhv001

Lindquist, K. A., Wager, T. D., Kober, H., Bliss-Moreau, E., \& Barrett, L. F. (2012). The brain basis of emotion: a meta-analytic review. Behav Brain Sci, 35(3), 121-143. doi: $10.1017 / \mathrm{S} 0140525 \mathrm{X} 11000446$

Major, B., Blodorn, A., \& Blascovich, G. M. (2018). The threat of increasing diversity: Why many White Americans support Trump in the 2016 presidential election. Group Processes \& Intergroup Relations, 21(6), 931-940.

Major, B., Blodorn, A., \& Major Blascovich, G. (2016). The threat of increasing diversity: Why many White Americans support Trump in the 2016 presidential election. Group Processes \& Intergroup Relations. doi: 10.1177/1368430216677304

Mansbridge, J., \& Macedo, S. (2019). Populism and Democratic Theory. Annual Review of Law and Social Science, 15(1), 59-77. doi: 10.1146/annurev-lawsocsci-101518042843

Marcus, G. E., Neuman, W. R., \& MacKuen, M. (2000). Affective intelligence and political judgment. Chicago: University of Chicago Press. 
Marcus, G. E., Sullivan, J. L., Theiss-Morse, E., \& Stevens, D. (2005). The emotional foundation of political cognition: The impact of extrinsic anxiety on the formation of political tolerance judgments. Political Psychology, 26, 949-964.

McGregor, I., Zanna, M. P., Holmes, J. G., \& Spencer, S. J. (2001). Compensatory conviction in the face of personal uncertainty: Going to extremes and being oneself. Journal of Personality and Social Psychology, 80, 472-488.

Montmarquet, J. (1993). Epistemic virtue and doxastic responsibility. Lanham, MD: Rowman \& Littlefield.

Mudde, C., \& Rovira Kaltwasser, C. (2013). Exclusionary vs. Inclusionary Populism: Comparing Contemporary Europe and Latin America. Government and Opposition, 48(2), 147-174. doi: 10.1017/gov.2012.11

Mummendey, A., \& Wenzel, M. (1999). Social discrimination and tolerance in intergroup relations: Reactions to intergroup difference. Personality and Social Psychology Review, 3, 158-174.

Mutz, D. C. (2018). Status threat, not economic hardship, explains the 2016 presidential vote. Proc Natl Acad Sci U S A. doi: 10.1073/pnas.1718155115

Nai, A., \& Maier, J. (2018). Perceived personality and campaign style of Hillary Clinton and Donald Trump. Personality and Individual Differences, 121, 80-83. doi: 10.1016/j.paid.2017.09.020

Prasad, A. (2020). The organization of ideological discourse in times of unexpected crisis: Explaining how COVID-19 is exploited by populist leaders. Leadership, 16(3), 294-302. doi: $10.1177 / 1742715020926783$ 
Ray, R. D., \& Zald, D. H. (2012). Anatomical insights into the interaction of emotion and cognition in the prefrontal cortex. Neurosci Biobehav Rev, 36(1), 479-501. doi: 10.1016/j.neubiorev.2011.08.005

Rico, G., Guinjoan, M., \& Anduiza, E. (2017). The Emotional Underpinnings of Populism: How Anger and Fear Affect Populist Attitudes. Swiss Political Science Review, 23(4), 444-461. doi: 10.1111/spsr.12261

Rooduijn, M., van der Brug, W., \& de Lange, S. L. (2016). Expressing or fuelling discontent? The relationship between populist voting and political discontent. Electoral Studies, 43, 32-40. doi: 10.1016/j.electstud.2016.04.006

Rooduijn, M., Van der Brug, W., De Lange, S. L., \& Parlevliet, J. (2017). Persuasive Populism? Estimating the Effect of Populist Messages on Political Cynicism. Politics and Governance, 5(4). doi: 10.17645/pag.v5i4.1124

Schneider, S. P., \& Haas, I. J. (manuscript in preparation). Political threat, ideology, and conspiracy endorsement.

Skitka, L. J., Bauman, C. W., Aramovich, N. P., \& Morgan, G. S. (2006). Confrontational and preventative policy responses to terrorism: Anger wants a fight and fear wants "them" to go away. Basic and Applied Social Psychology, 28, 375-384.

Storbeck, J., \& Clore, G. L. (2007). On the interdependence of cognition and emotion. Cognition and Emotion, 21(6), 1212-1237.

Thorisdottir, H., \& Jost, J. T. (2011). Motivated closed-mindedness mediates the effect of threat on political conservatism. Political Psychology, 32(5), 785-811. doi: 10.1111/j.1467-9221.2011.00840.x 
Webster, D. M., \& Kruglanski, A. W. (1994). Individual differences in need for cognitive closure. Journal of Personality and Social Psychology, 67, 1049-1062.

Wike, R., \& Schumacher, S. (2020, February 27). Democratic rights popular globally but commitment to them not always strong, Pew Research Center.

Williams, E. A., Pillai, R., Deptula, B. J., Lowe, K. B., \& McCombs, K. (2018). Did charisma "Trump" narcissism in 2016? Leader narcissism, attributed charisma, value congruence and voter choice. Personality and Individual Differences, 130, 11-17. doi: 10.1016/j.paid.2018.03.010

Zagzebski, L. T. (1996). Virtues of the mind: An inquiry into the nature of virtue and the ethical foundations of knowledge. New York, NY: Cambridge UP. 